\title{
Suicide, fatal injuries and drowning among the crews of United Kingdom and Bermuda registered cruise and passenger ships from 1976 to 2018
}

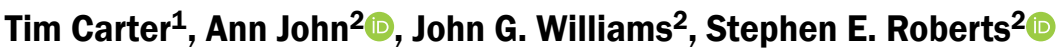 \\ ${ }^{1}$ Norwegian Centre for Maritime and Diving Medicine, Haukeland University Hospital, Norway \\ ${ }^{2}$ Medical School, Swansea University, Swansea, United Kingdom
}

\begin{abstract}
Background: Little has been reported about mortality among crews in passenger shipping. The aim of the study was to determine the detailed causes and circumstances of deaths from unnatural causes among crews employed in United Kingdom (UK) and Bermudan registered passenger shipping, their trends, how they relate to the type of passenger ship and crew rank and to discuss preventative measures.

Materials and methods: A longitudinal study from 1976 to 2018, based on reviews of marine accident investigation reports, death inquiry files, cruise shipping websites and online searches.

Results: One hundred and forty crew fatalities in UK (127) and Bermudan (13) passenger ships were identified: from accidents and drowning (91), suicides and disappearances at sea (38), homicide, other and unexplained causes (11). Over the 43-year study period, a reduction in mortality (per 1000 ship-years) from accidents and drowning was identified (mean annual reduction: 4.3\%; 95\% confidence interval: 2.1-6.5\%) but no significant reduction for suicides and disappearances at sea (annual reduction: 1.2\% confidence interval: $-1.3 \%$ to $+3.7 \%$ ). Most suicides and disappearances (70\%) were among customer service staff and, of 19 employed on large cruise ships, most (79\%) were non-Europeans.

Conclusions: The number of suicides and probable suicides is a cause for concern, especially among customer service staff on cruise ships. These findings indicate the need for interventions to reduce suicide risks. Further studies are needed to improve the targeting of interventions. These will need both to analyse the circumstances of individual deaths and derive suicide rates according to rank, department and nationality, based on reliable population denominators.
\end{abstract}

(Int Marit Health 2020; 71, 1: 12-19)

Key words: suicides, fatal accidents, cruise ships, passenger ferries, seafarers

\section{INTRODUCTION}

In recent years, several studies have reported on mortality in passengers who have sailed in cruise ships and/or other types of passenger vessels [1, 2]. Many other studies have reported on morbidity in cruise ship passengers, including injuries [3-5], various communicable diseases including gastroenteritis and influenza [3, 6-10], and acute cardiovascular diseases [11]. Little has been reported on mortality and its causes among crew members who serve on board cruise or passenger ships.
The main aims of this study were firstly, to determine the detailed causes and circumstances of fatalities from unnatural causes among crews employed in United Kingdom (UK) and Bermuda registered passenger ships from 1976 to 2018 , and how they relate to factors including their rank on board and the type of passenger ship in which they were serving. Secondly, to assess trends over time in mortality rates and to discuss preventative measures for reducing mortality.

Over many decades, increased or high suicide rates have been reported quite consistently among seafarers employed in 
merchant shipping across Europe, when compared with general populations [12-17]. This has led to increasing concerns in recent years about suicide risks and suitable preventative measures for seafarers. This study provides an opportunity to look at the distribution of events by type of ship and the rank of the seafarers dying from this cause in passenger shipping.

\section{MATERIALS AND METHODS INCLUSION CRITERIA}

This study examined reported deaths from unnatural causes among crew members who were "signed on" under articles of agreement (contracts) and working on board UK registered passenger ships of 100 gross registered tonnage and over between 1976 and 2018. The study included only those deaths that arose at work or within 30 days of any discharge ashore from work to hospital. This definition of passenger shipping includes cruise ships, passenger carrying ferries and a small number of other passenger vessels. As some of the major British cruise ships, such as the Queen Mary II, Queen Victoria, Arcadia and Caribbean Princess, have been registered or re-registered with the Bermudan ship registry (a register in the Red Ensign group, based in a UK Crown Dependency) the study additionally and similarly included all crew deaths in Bermudan registered passenger vessels during the same study period. In 2010, UK and Bermuda accounted for $6.7 \%$ of the world's 524 cruise ships and $2.8 \%$ of the world's 6810 passenger ships [18].

The study excluded deaths among crews who were employed in merchant vessels other than passenger ships, such as cargo and offshore supply ships, and in all other forms of water-craft.
Deaths among non-crew members such as passengers and port workers were also excluded, as were deaths that occurred when crews were signed off their ships. The study period was the 43 years from $1^{\text {st }}$ January 1976 to $31^{\text {st }}$ December 2018.

\section{STUDY INFORMATION SOURCES}

Deaths at sea, including work-related deaths, in British shipping have not usually been registered with the local registrars of deaths, nor included in central national mortality statistics or decennial census publications, but instead they have been registered separately at the Registry of Shipping and Seamen. Deaths from accidents, injuries, drowning and disappearances at sea are normally investigated by maritime authorities. In this study, details of deaths in UK and Bermuda passenger shipping were identified mainly from death inquiry files held by the UK's principle maritime investigative authority, the Marine Accident Investigation Branch and from death inquiry files and death registers at the Registry of Shipping and Seamen. Other information sources used include Lloyd's Register of Shipping casualty returns and data [19, 20], the British Newspaper Archive [21], cruise shipping websites and other online searches.

\section{POPULATIONS AT RISK}

The numbers of crew employed in UK and Bermudan passenger ships is not available from any information source. However, the numbers of passenger ships registered annually with the UK and Bermudan ship registries were obtained from Lloyd's Register of Shipping publications [18]. These show (Fig. 1) a very moderate reduction in the

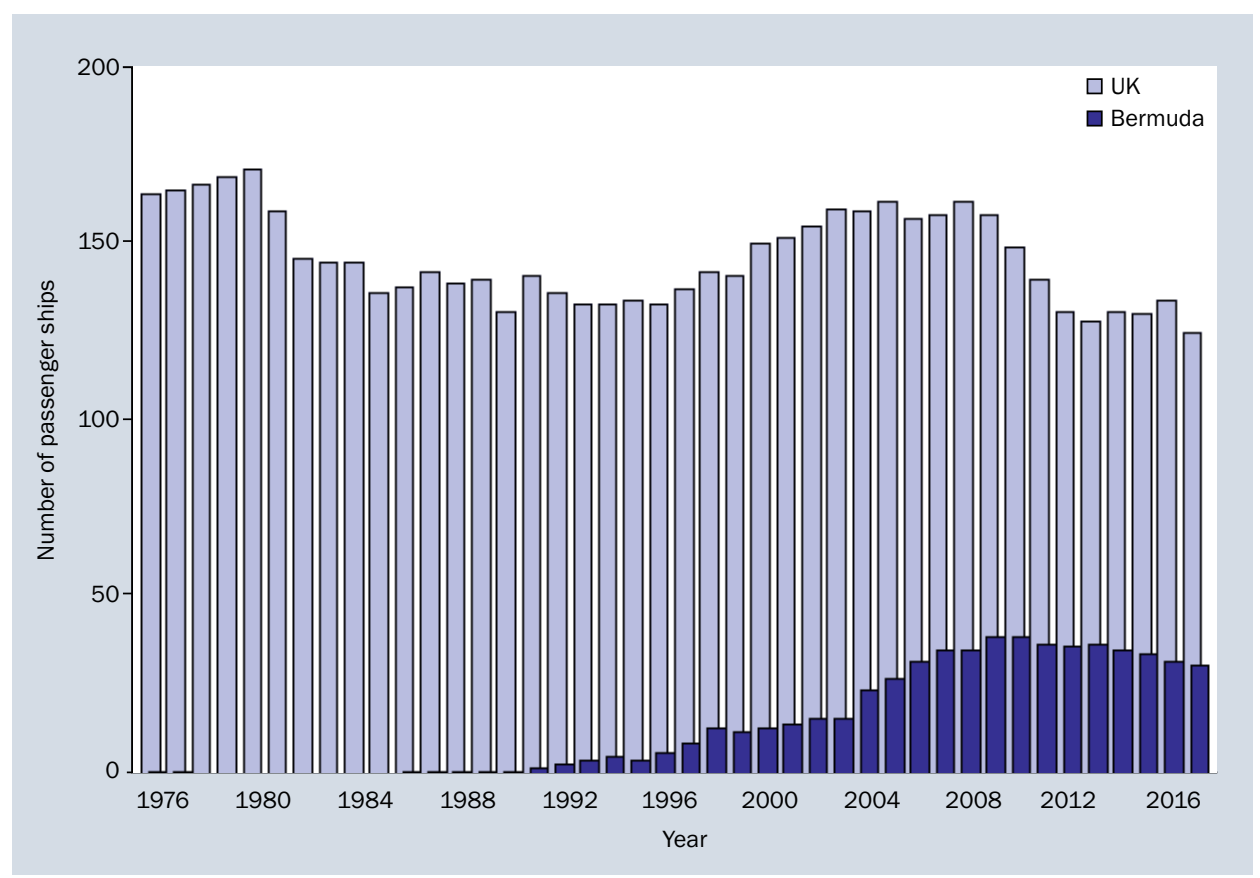

Figure 1. Numbers of United Kingdom (UK) and Bermuda registered passenger ships over time 
numbers of passenger ships under the two flags combined, particularly in the most recent years and with a modest interim peak in the years around 2005. However, both cruise ships and passenger ferries have increased in size over time, especially in the smaller Bermudan fleet through the registration of several very large cruise ships in the last 15 years, including the Queen Mary II and the Queen Victoria. Although crewing levels as well as the numbers of ships have fallen over time, increases in the sizes of the ships means that the total crew employed in UK and Bermudan passenger shipping is likely to have remained quite stable or increased slightly over the 43-year study period [18].

\section{METHODS OF ANALYSIS}

The main study factors assessed were, firstly, the rank of the deceased at the time of death, which was categorised as ship captains; deck officers; engineers; deck ratings; engine room ratings; and customer service staff. Two fatalities among radio officers were included with deck officers and two deaths among "other" staff were included with customer service staff, there were no deaths among cadets. The type of ship was classified into three categories; large cruise ships ( $\geq 40,000$ gross tonnage), small or medium size passenger ships (<40,000 gross tonnage) and passenger ferries (that mostly ranged 3,000-15,000 gross tonnage).

The main outcome measure was mortality by cause of death. Cause of death was grouped into accidents, suicides, homicides and other or unexplained causes. Historically, many crew have disappeared at sea, and these deaths have usually been categorised with suicides, while others that have been found drowned, often in docks and rivers when off-duty, have conventionally been included with accidents. A previous study of UK shipping found through examination of death inquiry files and crew statements that more than $80 \%$ of disappearances at sea were most likely suicides and that more than $80 \%$ of 'found drowned' cases were most likely accidents [22].

Accidents were grouped into three categories; ship accidents, involving an accident or incident to the passenger ship, such as capsize, foundering or fire; (on-duty) occupational accidents, affecting crews individually during work duties; and off-duty accidents which occur during leisure time. Mortality rates were expressed per 100 (passenger) ship-years. Logistic regression modelling was used to assess mean annual changes in mortality rates and their significance through 95\% confidence intervals $(\mathrm{Cl})$. Fisher's exact test was used to compare crew nationality groupings (British; other European; Asian; other nationalities; unspecified nationality) for seafarers who died through accidents and drowning, compared with suicides and disappearances at sea. Significance was based on the conventional $5 \%$ level.

\section{RESULTS}

Overall, there were 140 crew deaths identified, 127 in UK and 13 in Bermuda registered passenger ships. Apart from the Herald of Free Enterprise disaster in 1987, the passenger ships from which most crew fatalities occurred were the Queen Elizabeth II (11 deaths from 1978 to 2004), and the Canberra (7 deaths from 1976 to 1993).

One hundred and thirty-five of the 140 (96\%) were men, the mean age was 37.2 years (standard deviation [SD]: 11.9; range: $17-63$ years). 90 (64\%) of the 140 deceased were British. The remainder were other European (16), Asian (22), other nationalities (7) or unspecified nationality (5). The deceased were employed in the deck (39), engine (25) and customer service (86) departments.

The 140 crew fatalities were from accidents and drowning (91), suicides and disappearances at sea (38), homicide, other and unexplained causes (11; Tables 1 and 2).

\section{SUICIDES AND DISAPPEARANCES AT SEA}

Of 13 recorded as suicides, 6 jumped overboard, 6 were found hanged and 1 died through other means. 25 further crew who disappeared at sea also most likely jumped overboard, based on examination of death inquiry files, crew statements and marine accident investigation reports.

The mean age at death at the time of suicide or disappearance was 36.3 years (SD: 12.4; range: 18-61 years), $95 \%$ male. All but 5 of the 38 deaths arose at sea; from cruise or passenger ships in the North Atlantic and Caribbean Sea (7), North Pacific and South Pacific (8) and other seas (9) and from ferries around the UK (9).

Most of the 38 deceased (27; 71\%) were employed as customer service staff and most of these (19; 70\%) were employed on large cruise ships, the others were on ferries or small/medium size passenger ships. Of the 19 who were employed as customer service staff in large cruise ships, most (63\%) were Asian and three others were also non-European. In the most recent years, suicides and disappearances at sea largely involved customer service staff who were employed on board large cruise ships (Fig. 2). As reliable data on the crewing pattern on these vessels are not publically available it is not possible to compare rates of suicide, but only to point to the numbers of deaths.

There has been no significant reduction in mortality from suicides and disappearances over the 43-year study period (mean annual reduction: $1.2 \%$; $95 \% \mathrm{Cl}:-1.3 \%$ to +3.7\%; Fig. 3).

\section{MORTALITY FROM ACCIDENTS AND DROWNING}

The 91 fatal accidents and drowning include 46 from ship accidents, largely through the Herald of Free Enterprise disaster off Zeebrugge in 1987 (38 crew lost along with 155 passengers) and a collision between two passen- 
Table 1. Causes of all crew fatalities from unnatural causes in United Kingdom and Bermuda registered passenger ships, 1976-2018

\begin{tabular}{|c|c|c|c|c|c|c|c|}
\hline \multirow[b]{2}{*}{ Cause of death } & \multicolumn{7}{|c|}{ Rank of the deceased } \\
\hline & Captains & $\begin{array}{l}\text { Deck } \\
\text { officers }\end{array}$ & Engineers & $\begin{array}{l}\text { Deck } \\
\text { ratings }\end{array}$ & $\begin{array}{l}\text { Engine } \\
\text { room } \\
\text { ratings }\end{array}$ & $\begin{array}{l}\text { Customer } \\
\text { service } \\
\text { staff }\end{array}$ & (Total) \\
\hline \multicolumn{8}{|l|}{ Accidents and drowning } \\
\hline \multicolumn{8}{|l|}{ Ship accidents:* } \\
\hline Foundered or capsized & & 1 & 2 & 3 & 4 & 29 & (39) \\
\hline Collisions & & & 1 & 2 & 1 & & $(4)$ \\
\hline Fires or explosions & & & 2 & 1 & & & (3) \\
\hline \multicolumn{8}{|l|}{ Occupational accidents: } \\
\hline Lifeboat testing drills & & & & 3 & & & (3) \\
\hline Falls on board & & 1 & & 2 & & 1 & (4) \\
\hline Struck by mooring ropes & & 2 & & 1 & & & (3) \\
\hline Struck by motor vehicles on decks & & 1 & & & 1 & & $(2)$ \\
\hline Struck/crushed by watertight doors & & & & & 3 & 2 & (5) \\
\hline Struck by other moving objects & & & 2 & 1 & & & (3) \\
\hline Scalded in engine rooms & & & & & 2 & & $(2)$ \\
\hline Other occupational accidents & & & & 2 & 1 & & (3) \\
\hline \multicolumn{8}{|l|}{ Off-duty accidents and drowning: } \\
\hline Swimming or bathing accidents & & & & & 1 & 5 & (6) \\
\hline Traffic-related accidents ashore & & & 1 & 1 & 1 & 2 & (5) \\
\hline Falls on board & & & 1 & & & 1 & $(2)$ \\
\hline Falls in docks, returning to ship & & & & 2 & & 1 & (3) \\
\hline Other drowning & & & & 1 & & 3 & $(4)$ \\
\hline All other deaths from unnatural causes & 1 & & 1 & 14 & 1 & 32 & $(49)$ \\
\hline Total & 1 & 5 & 10 & 33 & 15 & 76 & $(140)$ \\
\hline
\end{tabular}

*Includes 38 crew fatalities through the capsize of the Herald of Free Enterprise passenger ferry

Table 2. Causes of all crew fatalities from unnatural causes according to the type of ship in United Kingdom and Bermuda registered passenger ships, 1976-2018

\begin{tabular}{|c|c|c|c|c|}
\hline \multirow[b]{2}{*}{ Cause of death } & \multicolumn{4}{|c|}{ Type of passenger ship } \\
\hline & $\begin{array}{l}\text { Large cruise } \\
\text { ships }\end{array}$ & $\begin{array}{l}\text { Small/medium } \\
\text { passenger ships }\end{array}$ & $\begin{array}{l}\text { Passenger } \\
\text { ferries }\end{array}$ & (Total) \\
\hline Accidents and drowning: & $13(25 \%)$ & $10(19 \%)$ & $30(55 \%)$ & $(53,100 \%)$ \\
\hline Ship accidents* & 1 & 1 & 6 & (8) \\
\hline Occupational accidents & 6 & 4 & 15 & (25) \\
\hline Off-duty accidents and drowning & 6 & 5 & 9 & (20) \\
\hline Suicides and disappearances at sea & $23(61 \%)$ & $3(8 \%)$ & $12(32 \%)$ & $(38,100 \%)$ \\
\hline Homicide, other and unexplained causes & 7 & 1 & 3 & (11) \\
\hline Total & 43 & 14 & 45 & (102) \\
\hline
\end{tabular}

*Excludes the 38 crew fatalities through the capsize of the Herald of Free Enterprise passenger ferry 


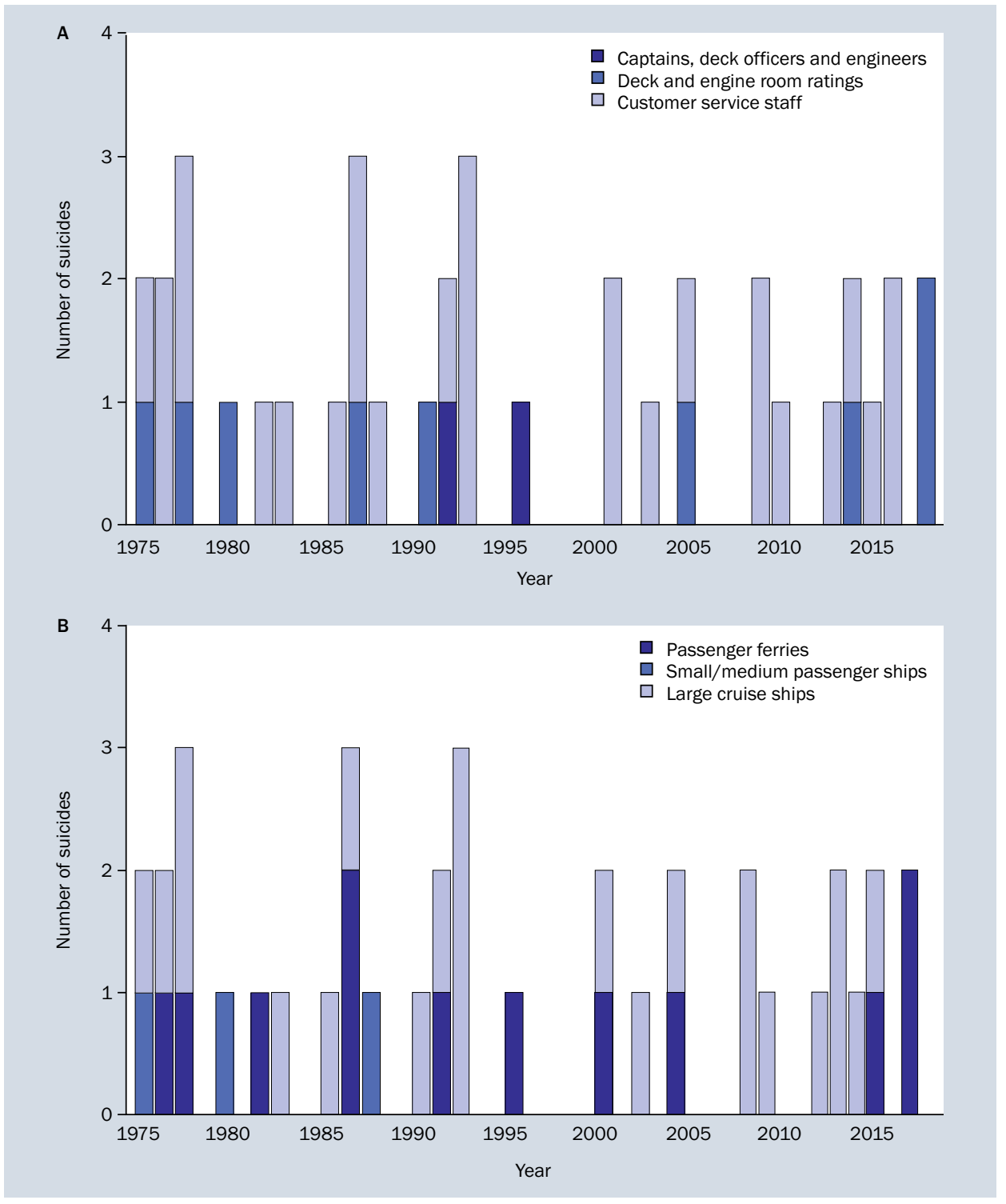

Figure 2. Trends in suicides and disappearances at sea among crew in United Kingdom and Bermuda registered passenger ships, 1976-2018, according to: rank of the deceased (A), and type of passenger ship (B)

ger ferries in the North Sea off Harwich in 1982 (4 fatalities). 25 fatal occupational (personal, on-duty) accidents or drowning refer largely to seafarers who were crushed in watertight doors, falls on board, vehicle injuries on ferries, struck by mooring ropes and davits breaking during lifeboat testing drills. 20 off-duty accidents and drownings were largely from swimming and bathing accidents from beaches, traffic accidents ashore and falls into or drowning in docks (Table 1).

The mean age at the time of accident or drowning was 37.0 years (SD: 12.1; range: $17-63)$. Three of the 91 (3\%) crew who died from accidents and drowning were female. 73 were British and 10 were other European, and 8 were Asian or of other or unspecified nationality, with a significantly different nationality profile to those who died through suicide or disappearance at sea $(p=0.002)$. Most fatal occupational accidents affected deck or engine room ratings (15;60\%), whereas most off-duty accidents occurred among customer service staff (12; 60\%; Table 1).

There has been a significant reduction over time in mortality from accidents and drowning (mean annual reduction: 4.3\% per annum; 95\% Cl: 2.1-6.5\%; Fig. 3).

\section{HOMICIDES AND OTHER DEATHS FROM UNNATURAL CAUSES}

Three homicides were due to injuries involving non-UK crew members of 2 large cruise ships and a UK crew member of an Irish Sea passenger ferry. Eight other deaths from 


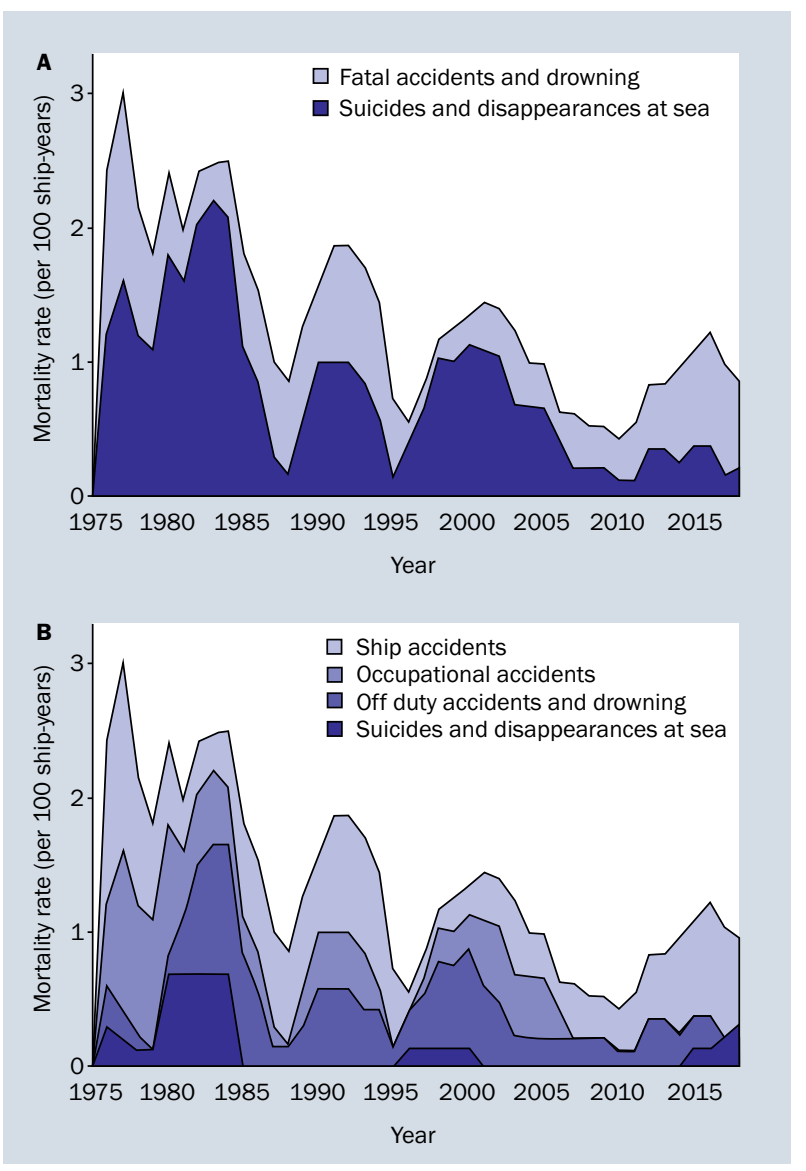

Figure 3. Trends in mortality from accidents and drowning, suicide and disappearances at among crew in United Kingdom (UK) and Bermuda registered passenger ships, 1976-2018; A. With types of accidents and drowning combined; B. With types of accidents and drowning disaggregated by type. Notes: Mortality rates are smoothed using 5 year moving averages. Excludes the 38 fatalities through the capsize of the Herald of Free Enterprise passenger ferry in 1987

unnatural or inconclusive cases were due to alcohol and drug intoxication (2), unexplained injuries (2), asphyxiation through an acute schizophrenia episode and on vomit (one each) and unspecified causes (2).

\section{DISCUSSION}

The study includes two related national ship registers and is limited to passenger vessels, a sector now dominated by cruise ships and passenger/vehicle ferries. Mortality from accidents is typically lower in passenger shipping than in cargo-carrying shipping sectors, where a high proportion of accidents are linked to cargo-related operations, such as asphyxiation or falls in cargo holds, cargo-related crushing injuries or falls overboard (which are largely absent in passenger shipping), as well as falls in docks when returning to ships from ashore and casualties involving small coastal-trading cargo ships [14, 22]. The reduction since the 1970s in mortality from accidents and drowning in passenger shipping is comparable with similar reductions over time in merchant shipping more generally [22].

It could be expected that ferries with their usually short and regular passages would have relatively lower case fatality than other forms of shipping, given speedy access to shore based services, while cruise liners, with their well equipped and staffed medical centres would also be expected to have better outcomes and hence lower mortality arising from injury events.

The outstanding feature of the study is the predominance of suicides and disappearances at sea in the cruise sector, with a stable level during the study period against a background of falling numbers of deaths from accidents and injury. The observation that a high proportion of suicides on large cruise ships occurred among, mainly Asian, male customer service crew, although the numbers were small, may reflect the high proportion of crewmembers from Asia who are performing these duties. It does however indicate the importance of targeting interventions to reduce suicide risk at this group if the overall numbers of suicides are to be reduced. Because of the limitations of the available data it is not possible to calculate mortality rates using the at-risk populations employed and so the number of ships registered has been used as a less than ideal surrogate for this. As in other studies [23], some deaths from other unnatural and unexplained causes may also have been due to suicide.

Recent reviews and reports have identified a number of uncertainties and controversies about the importance of suicide as a cause of death in seafarers and the contributory causes for this, notably the experience of social isolation among seafarers [24, 25]. Customer service staff, who are mainly recruited from Asian countries, tend to have longer periods away from their home and at sea, often of the order of 9 months, than other groups of crew. They may not define themselves as career seafarers and thus be accepting of the way of life on board, also they are working in an environment that is managed by crew with ethnic backgrounds and expectations that differ from their own. All of these aspects may exacerbate social isolation with its attendant risks. Findings from other sectors of employment indicate that low skilled trades, caring, leisure and other service occupations have high suicide rates relative to the general population $[26,27]$. Other contributory factors in these sectors, which may be in common with on board customer service crew, are socio-economic, including low pay, low job security and low socio-economic status [28]. The number of female suicide cases is low, especially in relation to the proportion of female customer service crew. This may reflect 
the lower incidence of suicide in females found in studies in other settings.

Strengths of this investigation are that it is the first study that has focussed specifically on the mortality of crews who are employed on board cruise and passenger ships. It is based on two large defined populations serving UK and Bermuda registered passenger ships and covers a long 43-year study period to assess trends in mortality. It is also based on reliable information sources that have been used in previous investigations of mortality in the maritime industries [16, 22, 23]. The major study limitation is that the numbers of crew employed in UK, Bermuda and almost all other passenger fleets world-wide are not known. Mortality rates have therefore been presented in terms of the much inferior numbers of passenger ship-years, rather than according to the person-years employed, so that the findings on trends in mortality should be considered as indicative. It is also likely that the notification, documentation and therefore study ascertainment of fatal accidents, through the maritime authorities, would have been more complete than for suicides and homicides.

\section{CONCLUSIONS}

These results do not immediately point to specific remedial actions, although recent reports do make a series of potential proposals, such as reducing stigma around mental health issues and social isolation, promoting positive social environments for staff on-board seafarer communities and peer support programmes [29]. Our findings would be enhanced by improvements in the documentation of non-accidental deaths in passenger shipping and in the maritime industries more generally, compared with that for fatal accidents. Also by further studies in the cruise sector that would be able to assess the detailed circumstances surrounding incidents of suicide and disappearance at sea using psychological autopsy methodologies as well as using baseline population information on gender, age, ethnicity, rank and ship department in the populations at risk.

\section{ACKNOWLEDGEMENTS}

The authors thank Cathy Pennock, Audrey Hodges and the Marine Accident Investigation Branch for helpful advice and provision of marine accident investigation files; John Crilley and Vaughan Pomeroy for help and advice with Lloyd's Register of Shipping casualty returns and data; and librarians at the Registry of Shipping and Seamen for providing access to death inquiry files and death registers.

\section{REFERENCES}

1. Dahl E. Passenger mortalities aboard cruise ships. Int Marit Health. 2001; 52(1-4): 19-23, indexed in Pubmed: 11817837.
2. Oldenburg M, Herzog J, Püschel K, et al. Mortality of German travellers on passenger vessels. J Travel Med. 2016; 23(1), doi: 10.1093/ jtm/tav003, indexed in Pubmed: 26782123.

3. Bansal V, Fortlage D, Lee JG, et al. Significant injury in cruise ship passengers a case series. Am J Prev Med. 2007; 33(3): 219-221, doi: 10.1016/j.amepre.2007.05.004, indexed in Pubmed: 17826583.

4. Bekic M, Mikolaucic M, Golubovic M, et al. A three-year follow-up on injuries sustained by cruise ship passengers and crew treated at the Orthopaedic and Traumatology Department at Dubrovnik County Hospital. Injury. 2015; 46 Suppl 6: S73-S77, doi: 10.1016/j. injury.2015.10.039, indexed in Pubmed: 26612476.

5. Isom WJ, Accilien YD, Chery SB, et al. Patterns of injury amongst cruise ship passengers requiring hospitalisation. Int Marit Health. 2018; 69(4): 243-247, doi: 10.5603/IMH.2018.0039, indexed in Pubmed: 30589063.

6. Rooney RM, Cramer EH, Mantha S, et al. A review of outbreaks of foodborne disease associated with passenger ships: evidence for risk management. Public Health Rep. 2004; 119(4): 427-434, doi: 10.1016/j.phr.2004.05.007, indexed in Pubmed: 15219800.

7. Cramer EH, Blanton CJ, Blanton LH, et al. Vessel Sanitation Program Environmental Health Inspection Team. Epidemiology of gastroenteritis on cruise ships, 2001-2004. Am J Prev Med. 2006; 30(3): 252-257, doi: 10.1016/j.amepre.2005.10.027, indexed in Pubmed: 16476642.

8. Schlaich CC, Oldenburg M, Lamshöft MM. Estimating the risk of communicable diseases aboard cargo ships. J Travel Med. 2009; 16(6): 402-406, doi: 10.1111/j.1708-8305.2009.00343.x, indexed in Pubmed: 19930380.

9. Payne M, Skowronski D, Sabaiduc S, et al. Increase in Hospital Admissions for Severe Influenza A/B among Travelers on Cruise Ships to Alaska, 2015. Emerg Infect Dis. 2018; 24(3): 566-568, doi: 10.3201/eid2403.171378, indexed in Pubmed: 29460744.

10. Pavli A, Maltezou HC, Papadakis A, et al. Respiratory infections and gastrointestinal illness on a cruise ship: a three-year prospective study. Travel Med Infect Dis. 2016; 14(4): 389-397, doi: 10.1016/j. tmaid.2016.05.019, indexed in Pubmed: 27320130.

11. Novaro GM, Bush HS, Fromkin KR, et al. Cardiovascular emergencies in cruise ship passengers. Am J Cardiol. 2010; 105(2): 153-157, doi: 10.1016/j.amjcard.2009.09.004, indexed in Pubmed: 20102910.

12. Otterland AA. sociomedical study of the mortality in merchant seafarers. Gotebörg: Scandinavian University Books. 1960.

13. Wickström $G$, Leivonniemi A. Suicides among male Finnish seafarers. Acta Psychiatr Scand. 1985; 71(6): 575-580, doi: 10.1111/j.16000447.1985.tb02551.x, indexed in Pubmed: 4024973.

14. Hansen HL. Surveillance of deaths on board Danish merchant ships, 1986-93: implications for prevention. Occup Environ Med. 1996; 53(4): 269-275, doi: 10.1136/oem.53.4.269, indexed in Pubmed: 8664966.

15. Szymańska K, Jaremin B, Rosik E. Suicides among Polish seamen and fishermen during work at sea. Int Marit Health. 2006; 57(1-4): 36-45, indexed in Pubmed: 17312692.

16. Roberts SE, Jaremin B, Chalasani $P$, et al. Suicides among seafarers in UK merchant shipping, 1919-2005. Occup Med (Lond). 2010; 60(1): 54-61, doi: 10.1093/occmed/kqp133, indexed in Pubmed: 19805397.

17. Iversen RTB. The mental health of seafarers. Int Marit Health. 2012; 63(2): 78-89, indexed in Pubmed: 22972547. 
18. Lloyd's Register of Shipping. World fleet statistics [annual returns, 1976-2018]. London: Lloyd's Register of Shipping: 1977-2019.

19. Lloyd's Register of Shipping. Casualty data (casualty data from Lloyd's Register.

20. Lloyd's Register of Shipping. Casualty returns, 1976-2010. London: Lloyd's Register of Shipping: 1977-2011.

21. British Newspaper Archive (www.britishnewspaperarchive.co.uk; last accessed September 18th. 2019.

22. Roberts SE, Marlow PB. Traumatic work related mortality among seafarers employed in British merchant shipping, 1976-2002. Occup Environ Med. 2005; 62(3): 172-180, doi: 10.1136/ oem.2003.012377, indexed in Pubmed: 15723882.

23. John A, McGregor J, Jones I, et al. Premature mortality among people with severe mental illness - New evidence from linked primary care data. Schizophr Res. 2018; 199: 154-162, doi: 10.1016/j. schres.2018.04.009, indexed in Pubmed: 29728293.

24. Carter T, Williams JG, Roberts SE. Crew and passenger deaths from vessel accidents in United Kingdom passenger ships since 1900. Int Marit Health. 2019; 70(1): 1-10, doi: 10.5603/IMH.2019.0001, indexed in Pubmed: 30931511.
25. Mellbye A, Carter T. Seafarers' depression and suicide. Int Marit Health. 2017; 68(2): 108-114, doi: 10.5603/IMH.2017.0020, indexed in Pubmed: 28660614.

26. Windsor-Shellard B, Gunnell D. Occupation-specific suicide risk in England: 2011-2015. Br J Psychiatry. 2019 [Epub ahead of print]: 1-6, doi: 10.1192/bjp.2019.69, indexed in Pubmed: 30929655.

27. Office for National Statistics. Suicide by occupation, England: 2011 to 2015. http://www.ons.gov.uk/peoplepopulationandcommunity/ birthsdeathsandmarriages/deaths/articles/suicidebyoccupation/ england2011to2015 (last accessed September 18th 2019).

28. Agerbo E, Gunnell D, Bonde JP, et al. Suicide and occupation: the impact of socio-economic, demographic and psychiatric differences. Psychol Med. 2007; 37(8): 1131-1140, doi: 10.1017/ S0033291707000487, indexed in Pubmed: 17445281.

29. Summary report from the ITF Seafarers' Trust Autumn 2016 workshop on social isolation, depression and suicide (SIDS). www. seafarerstrust.org/wp-content/uploads/2018/07/Seafarers-Social-Isolation-Depression-and-Suicide-Workshop-Write-Up-August2016. pdf (last accessed September 18th 2019). 